\title{
Women in the Bible: What can they teach us about gender equality?
}

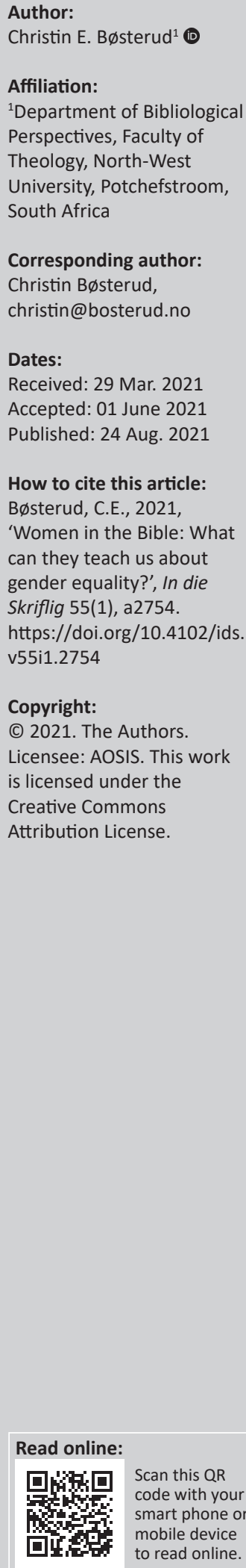

What can we learn about gender equality from the women in Scripture today? Can women in Scripture serve as role models for the women striving for leadership positions and could there be a potential correlation with current-day policies and practices supporting gender balance, and Christian ethical standards? This article, based on the Reformed paradigm, addresses women portrayed in formal and informal roles spanning from leaders, teachers, prophets and other prominent characters - each playing their roles in Scripture. It is argued that despite women often being placed in marginal positions in Scripture, they nevertheless permeate the Bible in narratives on resourcefulness, auto-leadership, and in their place in securing and upholding the Covenant with God. It will be demonstrated how women are presented as necessary partakers in the most significant of biblical narratives, and that their leadership exertion typically has a necessary role in the overarching scriptural scenarios. It will appear that by taking a closer approach to Scripture, we can take inspiration from female biblical leadership figures in most, if not all realms of today's life.

Contribution: It will be clear that Scripture lends sufficient support to promote full and complete gender equality, whether this be expressed in corporate life, government, or family. The examples gleaned from Scripture will demonstrate how gender equality not only is something that Scripture allows, but also expects.

Keywords: gender equality; female leadership; auto-leadership; auto-organisation; imago Dei; teaching.

\section{Introduction}

In our contemporary political discourse in the Western world, with increasing focus on women's rights in society and organisational life, where movements such as the \#metoo and the general political and media emphases on equal rights among the genders, a pertinent question will be what we can learn from the Bible in relation to matters of gender equality. This is not a new idea but highly necessary, as some Christian milieus have for centuries promoted scriptural interpretations and organisational practice whereby women have not been given full and equal access to all levels of influence, whether in organisational or personal life. An example here can be how women, for example here is how women, in some Christian denominations cannot hold certain formal offices, such as being allowed onto the priesthood. In this article, which is based on the Reformed paradigm, some central scriptural narratives involving women will be examined in a topical historical sense, and ascertain whether the Bible promotes full gender equality on all levels of society, where our core focus will be on women in leadership positions. The core question addressed, will be whether a Christian leader in the field of business or government agencies can draw on the Bible for promoting gender equality in leadership positions. The assumption here will be that such biblical support may be drawn, not in the least, when seeking the plausibility of biblical ethics in a modern environment. In the following article the place and role of women in the biblical tradition will be explored, as these are explained by Reformed theologians who adheres to the plausibility of a consistent biblical ethics.

For the purposes here, it will be of interest to seek out scriptural passages that promote women residing in positions of societal prominence or leadership, whether as formally appointed, or by wielding leadership in practice. From such scriptural examples, guidance will be sought for ascertaining how the Bible promotes gender equality on all other levels of society, with valid application in the modern society. Examples will be drawn from different scriptural sources of contextual significance, to be able to point to a conceptual taxonomic relevance outside the scriptural imagery in use and their direct biblical narrative utility. The scope here will allow only for a broad presentation but it is expected to render a sufficiently overview on how female leadership permeates Scripture, at least for those willing to look. In my personal experience, 
modern leadership may get inspiration, motivation and support from biblical sources, especially relevant to women due to the lack of gender balance at top management level (Bøsterud 2020).

\section{Overall perspective}

In several parts of the Bible, women are portrayed as marginal figures who reside in the shadows given subordinate roles. However, there are some outstanding exceptions like Sarah, Rebekah, Rachel, Miriam, Deborah and Esther in the Old Testament and Mary, mother of Christ and Mary Magdalene in the New Testament, all of whom are significant role models, within their different narratives. They all come across as honestly portrayed proving faithful and useful input to humanity, even though women to some extent, were given unjustified 'bad press' after the Fall (Gn 3:23) in several scriptural passages. From Eve to Jezebel, women are regularly blamed for the challenges presented to the people of Israel and their ancestors. More likely, the roles women play in the Old Testament may be a direct consequence of the increasing patriarchal influence on society and religion. As addressed below, God created Eve and Adam as equals (Gn 1:27) and the early Israelite women held important positions equal to men, as prophets, leaders and judges (e.g. Jdg 4:4; Es 2:17). Some women in Scripture even became heroes in their nations, and although these may not be recognised in secular historical accounts, their portrayal in the Bible signals the importance of their roles and participation in the history of salvation (Baldock 2018).

\section{Equality under the creation (imago Dei doctrine)}

The creation narratives in Genesis 1:26-27 and 2:18-24 highlight a special place in creation for the human family. This appears from the fact that humans are likened to God in that He created them in his own image, as it appears in Genesis 1:27: 'So God created mankind in his own image', which in systematic theology is referred to as the imago Dei doctrine. The aim here is not to elaborate the imago Dei doctrine in any deep detail, but to see the doctrine from a gender equality point of view, for possible relevance in the contemporary gender-ethical discourse.

When referring to imago Dei and gender, two essential topics surface: firstly, God's way of actualising himself through humans, and secondly God's love for humans. Stating that human beings are created in the image of God, entails that natural human qualities enable God to be manifested within human beings. Consequently, humans are the tools God uses to communicate and demonstrate his plans and purposes, thus recognising the role humans play as co-creators together with God. An essential ethical implication of the doctrine of imago Dei is love - our love for God, our love for other humans, and God's love for us. Pertaining to the creation of the woman, Scripture does not only support her as a full human being, but also differentiates her as superior to other creatures alongside with her counterpart, the male human being (Gn 1:26-27; 2:18-24). In her relationship to the male human, the woman is described as his counterpart and equal partner, holding an intimate relationship as a collective team, a team that is necessary for the performance of God's plans for humanity and the wider creation (e.g. Gn 1:28; Ps 24:1).

The second creation narrative, found in Genesis 2:21-24 has, however, given room for interpretation. Both the method of creation, i.e. the woman being created from the rib of the man, and its timing have been argued to support male superiority in relation to women, although under such argumentation, there will be a need to disregard how both were created 'in his image' (Gn 1:26). It may also easily be argued that the imagery in Genesis 2 does not support viewing the female as inferior; on the contrary, perfection and completion is reached only when she is created. The Talmud even supports going further, implying that God created Eve with greater mental capabilities than Adam (Stewart 2012a).

A further approach may very well be to regard the second creation narrative as emphasising the unity between the two sexes, underlining the fellowship of the two sexes. Being created out of a rib, supports equality between the sexes, as the rib may be a neutral part of the body, whereto no specific folkloric or semiotic human traits are typically assigned (Stewart 2012a). If she had been made either from his head or from his feet, this could have indicated that she would either rule over him or be ruled by him. The female being created out of the rib of the male (Gn 2:23-24) can be argued to underline the closeness between the sexes, as men and women are one. A notable part is also the description of the relationship as harmonious, lacking any focus on sexual differences, as they 'were both naked, and they felt no shame' (Gn 2:25). Hence the difference at this stage was in sex and not in nature.

Irrespectively, it should be noted that adam in Hebrew can have different meanings, spanning from the soil from which 'adam' was created, via 'humankind' or 'humanity', to the personal name Adam. Hence, the use of 'adam' does not automatically refer to the male sex, supporting equality between men and women as created in the image of God (Alexander \& Baker 2002; Alter 2018).

While the Fall narrative (Gn 3) may be read as a punishment of females, introducing her to the challenge of childbirth, due to her disobedience leading to the Fall, another angle may be added, introducing the female as the protagonist. She is portrayed as leaning forward, hungry for knowledge while testing borders, or in short, being human, demonstrating the traits found in mythical and real-life heroes and leaders, while also opening the door to birth and death. To some the Fall is an enchanting story of a women deceived by a snake, with the rather comical, passive bystander of a man. To others, Eve is far from victimised by a snake, as she consciously chooses knowledge, while Adam's action can be viewed as passive disobedience, even blaming Eve for his actions (Gn 3:12). The sequences in Genesis 2 and 3 leading to 
the Fall, also raise interesting questions. Who, for example told Eve about the tree? After all, Eve was created (Gn 2:22) after God told Adam not to eat the fruit from the tree (Gn 2:17). Moreover, Eve was also led to believe that touching the tree would kill her, not only eating from it (Gn 3:3). It is tempting to state that something is missing from the picture; could she have been misled by Adam? Is that why he acted so passively during the whole event (Stewart 2012a)? Also, if Eve alone was responsible for the Fall, why was Adam punished (Gn 3:17-19)?

Whether Adam or Eve alone is to blame, is further addressed in the New Testament. In 1 Timothy 2:13-14 Eve is seen as the perpetrator, while Romans 5:12 shifts to Adam and him alone: 'just as sin came into the world through one man ... so death spread to all because all have sinned'. Even though many have blamed Eve for our fractured position, even as the gateway to the abyss, an important aspect, with respect to equality, is Eve's role as 'mother of all the living' (Gn 3:20) quite a significant role in the history of humans. With this backdrop, Eve may indeed be claimed as a powerful protagonist, displaying both intellect and intrusiveness, created in the image of God (Baldock 2018; Stewart 2012a).

\section{The matriarchs}

Even though many of the women mentioned in Scripture are nameless, the Old Testament matriarchs have made a noticeable mark on history on multiple levels (Niditch 2012).

In Isaiah 51:1-2, we are reminded of the inherent equality between the sexes, setting the scene for some of the greatest matriarchs like Sarah, Rebekah, Tamar and Rachel.

Sarah, who was married to Abraham, plays a visible role in quite enigmatic events, like giving birth at the age of 95 years, after arranging that her husband had a child with her servant Hagar (Gn 17:16). She also reflects courage and independence, when she was eavesdropping during Abraham's talk to God and even laughing at God stating that she would become pregnant (Gn 16:12-15). Another notable part of the story is that Hagar was Sarah's property (Gn 16:1-6), implying that during these times women still had the ability to own and dispose of property, rights that gradually disappeared and did not resurface until the early 1900s in most parts of the Western world, though not in all (De Riencourt 1989).

Though somewhat confusing, the stories about Sarah reveal an energetic person with an activity level making her overshadow her husband (e.g. Gn 16:6), a perhaps surprising position within an apparently patriarchal environment. Some claim that her role needs to be viewed from a matriarchal angle, as would be common in Mesopotamia for women carrying the role of a priestess. A woman holding such positions did not only retain a highly privileged position within society, but also vis-à-vis her husband (Teubal 1984). One further observation with respect to Sarah is what may be God's empowerment of Sarah when she chose Isaac and turned away Hagar and Ishmael (Gn 21:10), a decision God by action respected, by caring for the two after Sarah forced them to leave her house (Gn 16:4; 21:14-20).

Another intriguing woman in the Bible is Rebekah, portrayed as a woman in full control, moving the men in her life around as puppets in a show (e.g. Gn 24:1-67; 25:19-28; 26:1-11). Her wisdom is easily recognised through her ability to listen and pull the needed strings to meet her goals, always working behind the scenes. Her power may not be the empowerment sought by women of today, as it lacks formal authority. However, she is portrayed with many of the traits associated with heroines, such as being smart, strong and self-confident, as well as superior to the men around her when it comes to wisdom and political dealings (e.g. Gn 27:5-14), thus displaying women's powers in a male-dominated world by applying playfulness, comedy and trickery (Niditch 2012).

Tamar (Gn 38:6-30) is portrayed as a smart woman, also using trickery as a tool in her fight for survival. After she had been deceived by her father-in-law following her wicked husband's death (Gn 38:14), she finds herself at the bottom of society: a widow without any children (Gn 38:11). Recognising her own challenges, she hides her identity and takes on the role of a prostitute, thereby seducing her father-in-law (Gn 38:18) subsequently forcing him to take care of her (Gn 38:25). Noticeably, Tamar's son Perez is one of the forefathers of Boaz, who married Ruth; thus, both Tamar and Ruth are matriarchs with bloodlines leading to David, the greatest hero of Israel (Rt 4:18).

The story of Rachel (Gn 29) is a captivating story of love conquering lies. Jacob fell in love with her and worked for her father for seven years before being allowed to marry her (Gn 29:18). During the marriage ceremony, Rachel's father deceived Jacob to marry her less appealing older sister Leah and demanded that Jacob should work for another seven years to earn his right to marry Rachel. Even in this situation, Rachel never lost her love for Jacob (Gn 29:27-29). She is another of the great scriptural matriarchs struggling to conceive children, however, her awaited first-born son, Joseph (Gn 30:22), lived to be one of the most important characters in the Hebrew Bible, saving Israel from famine (Gn 47:13-27). Rachel's second son, Benjamin, also turned out to be a significant person, namely one of the 12 progenitors of Israel (Gn 35:16-18). Another interesting part of Rachel's story is her loyalty to her husband and not her father, who effectively sold both her and her sister Leah. This may be the reason why Rachel stole goods from her father and hid her action by lying about having her period (Gn 31:19, 35). One may ask if this is rebelling against a despiteful father, or whether this is reflecting Rachel's independent and strong character, or a combination of both. There is no doubt that Rachel displays a woman's power by acting as she does, also reducing her father's overt authority through her resourcefulness (Niditch 2012).

It is evident from the above that the matriarchs of the Bible were self-motivated leaders, and that they were willing to accept leadership tasks of the utmost importance 
for their families, their people, and the survival of Israel, rendering them an important role in maintaining the Covenant with God.

\section{Crises and war}

Women have throughout time played an active role in times of crises and war. The Hebrew Bible holds many stories of nameless women as victims of war, such as being women killed during the holy war (1 Sm 15:3), or the killing of women alongside men in war or an attack (1 Sm 15:33; 22:19). Disposing of witnesses to crime (1 Sm 27:9, 11) and women as captive hostages (1 Sm 30) are other examples.

Shiphrah and Puah, who are colloquially known as the Hebrew midwives, were instructed by the Pharaoh to kill all Hebrew boys at birth, during the politically unstable situation affecting Egypt. By disobeying this order, the midwives exerted crucial auto-leadership that allowed the population of Israel to grow, while displaying both bravery and resistance in an effective though dangerous way (Ex 1:15-21). That the leadership and bravery was acknowledged favourably by God, is reflected in that the midwives themselves were given 'families of their own' (Ex 1:21) by God.

In Exodus 2:1-8, courage, leadership and love during a critical situation is also demonstrated by the other women from Moses' childhood, firstly his mother shielding him for three months before she 'placed the child in it and put it among the reeds along the bank of the Nile' (Ex 2:3); secondly his sister who followed him down the river to ensure his safe journey (Ex 2:4); and thirdly the daughter of the Pharaoh, who found him, and despite recognising him as 'one of the Hebrew babies' (Ex 2:6), she disobeyed her father's orders, saved the child and unknowingly hired his birth mother to care for him in their own household (Ex 2:8). All three women displayed heroic actions and independent leadership, saving Moses in the middle of the great oppression, and thus securing the continuation of Israel.

Another interesting female character is Rahab the Canaanite, who is referred to as a prostitute (Jos 2:2). Her faith in God makes her courageously ignore the king's order, and hide the Hebrew spies, as well as plotting their escape, while, with her own life at risk, distracting the pursuers (Jos 2:1; 2:3; Ja 2:25). She is portrayed as a resourceful and brave woman compared to the spies, who promised to save her, and her family's lives when they return in armour (Jos 6:17-25). Her shrewdness and proactive approach are easy to detect, and the reason for her actions is her prophetic recognition that God already had awarded the land to the Hebrews. Her speech to the spies offers the confidence they need, together with the military strategy required to successfully conquer the Canaanites. Rahab later marries Salmon from one of the leading families of Israel, thereby becoming a foremother to Jesus (Mt 1:5), something which may point to the universalistic nature of Christianity: Rahab, as a gentile woman, is allowed into the most important genealogy of all.
A female protagonist who forcefully handles conflict and the political games of power, is Esther. She is portrayed as a remarkable woman of principle, willing to risk her life to save her people. Esther's book was heavily debated during the early centuries of Christendom, which did not easily receive its canonical status, and the story of Esther could be challenging to interpret also today (Frymer-Kensky 2004; White Crawford 2012). There are several reasons for this. Firstly, God is completely absent in the narrative, and secondly no laws or covenants are mentioned, neither are there any signs of prayer. Irrespective of this, Esther's book is seen by some as the most worldly in the whole Hebrew Bible (White Crawford 2012).

Esther's role as a heroine takes her via the harem of the king to become his queen. Through her Jewish guardian Mordecai, she is made aware of a plot to kill the king, and by reporting the plot she successfully saves the king's life (Es 2:22-23). During the next step of the story, Esther uses her political skills to save the Jews in the Persian Empire from a plot to annihilate them. By averting the deadly plot, she ensured the destruction of the enemies of the Jewish nation and positioned Mordecai as the next in line to the king (Es 10:3).

An intriguing part of Esther's book is the use of humour and irony to address both existing and absent power, in addition to the ethical challenges and the peril of genocide, as well as the sin of arrogance with subsequent consequences. There is, for example irony in the fact that the protagonist is a Jewish female orphan, presumably as low-ranked as any because of her gender, nationality and her lack of parents. As the story is read, Esther must be assumed to be a person completely lacking power within the Persian Empire. Nevertheless, she climbs to the very top, while the assumed powerful man attempting to kill her, as well as Israel in totality. Esther comes clearly across as a leader, placed at the highest position of all the Jews in exile, using her position of relative power to lead her people to safety, in a self-motivated manner, without drawing on any significant male character for her leadership in decision making.

Judith is the fourth woman to have a biblical book named after her, albeit this book is in the Apocrypha. Among the judges of Israel specifically mentioned, all identified as charismatic leaders, Judith is the only female. She is portrayed as a beautiful, rich and pious widow who takes on a leadership role when the male members of her community are ready to surrender their town to the Assyrian aggressor (Judith 8:11). Single-handedly, Judith then designs a plan to deceive and kill the enemy's general, Holofernes (Judith 8:32-34). Judith's plan involves pretending to spy against her own people, something that was believed by the Assyrians, granting her access to the tent of Holofernes (Judith 10:20). She dupes him with her seductive powers and gets him drunk. In his drunken sleep, she beheads him (Judith 13:8), subsequently, bringing the head back to the Judeans, granting her the heroic position she deserved (Judith 13:20). When the Assyrians learn of the death of their general, panic strikes, and the Israelites cut them down in great numbers, regaining 
their properties and possessions from the Assyrian capture (Judith 15:5-7). The story ends with Judith being hailed by all, while remaining a widow in honour of her husband (Judith 16:21-22). Judith's story resembles a much shorter narrative found in the canonical Scriptures, in Judges 4 and 5, where the Kenite woman Jael kills the fleeing Canaanite enemy general Sisera while hiding him in her tent. Jael kills Sisera with a tent peg she hammers through his temple while he was sleeping (Jdg 4:21). The narrative is mentioned both in Judges 4 as a story, and in Judges 5 as part of Deborah's song (Jdg 5:24-27), something that lends significant importance to the story, and which gives the more detailed story in Judith stronger interpretative relevance, despite its apocryphal position.

Judith's story also bears a strong resemblance to that of Esther, as she acts when men cannot. To protect her people, she demonstrates courage and to some extent one may say that she embodies the tensions of ancient Jewish life, reflected both at the personal and national level. With respect to the latter, her story includes God's test of people, God's response to prayer and sacrifice, and God's response to people of faith, albeit with Judith as the facilitating actor. The stories of Judith and Esther thus bear strong resemblance to each other as female protagonists in a man's world. Both chose extraordinary methods in times of crisis, lifting them out of the rigid patriarchal environment of their times, that guided the relationships between males and females (Reinhartz 2012).

An interesting aspect of the story of Judith is that men play the key roles in the early chapters and Judith first appears in the eighth chapter. When the frightened Jews prepare for the invasion, the vulnerability of women and children during the war is envisioned (e.g. Judith 4:12; 7:22, 32), implying rape and killing of the women by the conquerors. This backdrop makes Judith's actions even more radical when we appreciate that she lives the life of a wealthy widow bathing in water while children and women are fainting in the streets because of thirst. Nevertheless, she unselfishly takes on the leadership task to save her people, speaking to the elders with authority, claiming power and wisdom, being truly upset that her fellow Jews do not trust that God will save them. Using her wits and cunning, Judith can act as the saviour of Israel from the ruthless invader. To many, Judith is seen as a role model for women of today, displaying beauty, wisdom and control over her own life and destiny (Dombkowski Hopkins 2012). The reference to judges being charismatic leaders, is also quite interesting in modern leadership theory, where charisma is one of the traits recognised as important within the theories on transformational leadership style (FrymerKensky 2004).

What is particularly noteworthy in the stories about Esther, Judith and Jael is that to reach their goals, they not only utilised political cunning, which at times may be a quality attributed to women, but also that they displayed acts of extreme violence (Jael and Judith), which typically would be connected to men, and seen as an archetypical male trait. Furthermore, in Jael's case, her killing of Sisera was not even necessary in the plot, as Sisera's army had already fled, and even more, as a Kenite, it would not be expected of her to step up and save Israel. Thus, all three women mentioned here, accepted roles that are in no way subsidiary to those of men, neither in importance nor in execution, as the narratives clearly show women able to act independently of their male societal counterparts at all stages of the stories as they unfold, as well as being capable of performing acts of crucial importance in the continuation of Israel. The three stories eloquently portray women as equally important as men in securing the Covenant.

It is evident from the above, that women in the Bible have been given pivotal and critical roles in society in times of crises and war. And it has been shown that women can instigate auto-organisation, amidst the strenuous horrors of war and crisis on all levels.

\section{Women in the New Testament}

With Jesus, a new era for womanhood arose. Not only was He born from a woman, his followers and ministry included numerous women. Through Jesus' teachings in the New Testament, women's roles are further enhanced, namely through Jesus' inclusion of women in his teachings and in women's devotion to him (Mt 5:27-32; Lk 10:38, 42). Jesus' high opinion and respect for women is visible in the way women were added to his group of followers, and Jesus' interplay with women is an essential part of any theological debate addressing Christianity and women. Women are very visible in Jesus' life: being delivered by a woman, meeting women at all stages of his life, and having been encountered first by a woman after his resurrection (Mk 16:9; Jn 20:14). He further commissioned women to share the story of his resurrection with the disciples, probably one of the most important messages of Christianity (Jn 20:17).

The essential part of the role women played in Jesus' life and teachings, is evident by their inclusion in most stories. The Gospels share a consistent story including women as part of Jesus' followers; his commitment to include them in his teachings is further breaking with tradition in the Judaism of his time. His teachings did not include explicit words delineating women as a separate class; on the contrary, they support the interpretation that every female should be viewed as an equal person in her own right. It is easy to argue from all three Synoptic Gospels that Jesus does not accept a hierarchy in Christian relationships, something which by logic would also be applicable to gender: 'You know that the rulers of the Gentiles lord it over them, and their high officials exercise authority over them. Not so with you' (Mk 10:42; par: Mt 20:26-26; Lk 22:25).

The stories of Jesus and his position with respect to women, clearly indicate the prominent role women played in the early church. Among the first followers, women were included (e.g. Ac 16:13-15), the apostles showed high respect 
to the women, praising them as part of the church (e.g., $1 \mathrm{Tm}$ 3:11; Tt 2:3-5; 1 Pt 3:1-6), and women also held official positions influencing the church spiritually ( $\mathrm{Rm} 16: 1$ ).

Mary of Nazareth, mother of Christ, is the most iconic female in the Bible and in Christianity, appearing in Scripture as a multifaceted, complex character embodying contradictions. She may be hard to capture, by being both recognised as virgin and the mother of Jesus, enduring confusion, fear and darkness as her life unfolded. Ironically, despite her central role in wider Christianity, her role in the New Testament is relatively minor.

Mary's scriptural story starts when giving her unqualified acceptance to God's plan for her life, including both personal risk, public and social disgrace (Mt 1:19; Lk 1:26-38), as well as unavoidable suffering (Jn 19:25). Although she may be scarcely described in Scripture, Mary has been assigned the most important role of all in raising and educating Jesus, and it is here of importance to note that from a perspective of ontological Christology, we do not know whether Jesus himself even knew that he was God, or of his part in the Trinity (Sanders 1995). As Christ in Trinity is fully human, the worldly tasks of Mary in being his mother, also fully human, cannot be overstated (O'Collins 2009). By accepting his full humanity - as, for example when he snaps at her at the wedding of Canaan (Jn 2:4) - we realise that Mary's tasks in giving birth and raising Jesus is a crucially necessary chore, and Mary accepted this great challenge with grace (Lk 1:38). From this it may be inferred that the most important 'senior' leadership role which is described anywhere in Scripture, will have been awarded to a female actress, Mary. For the purposes here, the above will suffice in describing the leadership tasks connected to Mary, although her loyalty to Jesus is unsurpassed in Scripture, as she was there to give birth to him (Lk 2:7), and she was also present by the cross in his last hours (Jn 19:25).

Another important woman in the life of Jesus, is Mary Magdalene. Numerous females bearing the name Mary are met in the Gospels (e.g. Jn 11:1), but there is only one Magdalene. When she appears together with other females, she is always singled out, or we find her name mentioned first (e.g. Mt 27:56; Lk 24:10), clearly indicating the significant role she plays in the Gospels. She is especially visible during Jesus' crucifixion, his burial and his resurrection.

According to the Synoptic Gospels, Mary Magdalene is the one who discovers the empty tomb, together with other women, and they are instructed to share the joyful news (Mt 28:1-10; Mk 16:1-8; cf. Lk 24:1-12). An interesting deviation from these stories is found in John, who singles her out not only as a witness to the crucifixion (Jn 19:25), but also names her as the first person Jesus reveals himself to after the resurrection (Jn 20:11-18). Through this she is also empowered to be among those to share this important news with his followers (Lk 24:10), indicating not only her central position but also that it is natural and acceptable to have a woman share such vital soteriological information like this. This is also emphasised in Mark 16:9, stating that Jesus showed himself to Mary before others, even his closest disciples Peter and John. She is the one sharing the greatest and most important news in Christian theology, that Jesus had risen from death, whereby she is sent by God to share this joyful message to the apostles (Jn 20:17).

A further striking aspect recognised in the New Testament, is the significant roles women played as leaders of the early churches. One example is Nympha, who is named as an

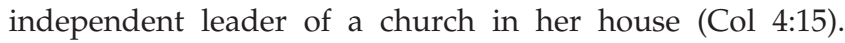
Similar stories mention the house of Mary (Ac 12:12-17) and the house of Lydia (Ac 16:14-15, 40), while Priscilla is one of the most influential women in Paul's letters, as she led a house church together with her husband Rm 16:3-5 and 1 Cor 16:19). These house churches are believed to have combined an arena for worship and meetings among the members of the early church, with dwellings for the inhabitants. Priscilla's ministerial and leadership skills are believed to have contributed to the foundation for congregations to grow and prosper in her house churches in different locations (Frymer-Kensky 2004).

Lydia's story associated with leadership of house churches, combining worship with the trade in purple cloth (Ac 16:11-15, $40)$, is interesting from several aspects: she, though a woman, owns real property, is involved in trade, and combines this with hosting church meetings.

In line with the above, it can responsibly be argued that the female spiritual leaders with titles like apostle or deacon were real-life leaders in practice, their titles being much more than honorary (e.g. Rm 16:1, 7). These females received their titles because of their own capabilities and skills, not through marriage or by way of any other male derivation (FrymerKensky 2004; Hylen 2018).

As addressed above, women mentioned in the New Testament were given roles of seminal and utmost importance in the life of Jesus and in subsequent church formation and missionary activity.

\section{Women in learning, apprenticeship and teaching}

A further compelling observation is Huldah who according to Jewish tradition, is one of the seven prophetesses. However, her formal roles and recognition in the narrative of Josiah's reform, makes her the most important prophet of the Deuteronomistic history (Scheuer 2015). Through her formal role, which may be described as a leader ordinated by God, Huldah was trusted by the king with serious matters. One of her prophecies ignited significant religious changes $(2 \mathrm{Ki}$ 22:14-20; 2 Chr 34:22-33; Willmington 2019).

A further significant prophet is Anna, who was a prophetess and one of the first to foresee Jesus' divine greatness, hence 
she may easily be seen as one of the most significant prophetesses in the whole Bible. After being widowed following a short marriage, Anna had abandoned herself fully to God, fasting and praying in the temple (Lk 2:36-37). As a woman, it can be assumed she was not granted access to the most holy place but was spending her time in the women's court (Baldock 2018). Anna's prophecy took place when Mary and Joseph visited this part of the temple with infant Jesus, to fulfil the ancient law whereby the first-born son should be dedicated to God ( $L k$ 2:22). When seeing the infant Jesus, Anna felt God's presence and 'gave thanks to God and spoke about the child to all who were looking forward to the redemption of Jerusalem' (Lk 2:38). This event not only transforms the women's court into the holiest part of the temple, but also reveals a scriptural ethos of gender equality by way of portraying a female actress who exerts leadership among her people, as God chose to share the news with a woman (Baldock 2018).

In addition to Mary the mother of Christ and Mary Magdalene, several other women followed Jesus, one being Mary of Bethany (Mt 26:6-13; Mk 14:3-9; Lk 10:38-42; Jn 11:1-12:3). She is portrayed as an unmarried woman, fully devoted to following Jesus. Though she was a woman of few words, her prophetic gesture of anointing Jesus' head with expensive perfume, reflected his coming burial (Jn 12:4-7). Her sister Martha also followed Jesus, being more active and pragmatic than Mary. Though her worries and concern for the smallest things were addressed by Jesus, she faithfully followed him as a friend and apprentice (Lk 10:38; Jn 11:1-12:3). The brother of Martha and Mary, Lazarus, was also a follower. An interesting observation is that whereas the sisters are active and vocal, there is no dialogue between Jesus and Lazarus, even though Jesus raised him from the dead (Jn 11:43).

Another female follower of Jesus was Joanna, who experienced how Jesus healed her, and chose to abandon her high-ranking role with Herod's court to support Jesus' ministry and join his flock of followers (Lk 8:1-3; 24:10). Salome joined Jesus after her two sons had left their father and his fishery. She chose to leave behind her comfortable home to follow Jesus, whom she truly believed to be the Messiah (Mt 20:20-24; 37:56; Mk 15:40-41; 16:1-2).

Though with different histories and backgrounds, all the women who followed Jesus not only shared love for Christ but can also be regarded as part of his spiritual apprenticeship, laying the foundation for the first ministries.

All four the Gospels report that most of those disciples who were present and gave their support when Jesus was crucified and died, were women; as for the male disciples, already at his arrest 'everyone deserted him and fled' (Mk 14:50). Furthermore, as predicted by Jesus, Peter expressly denounced him even the same night, as when asked about his connection to Jesus, he angrily swore to them, 'I don't know this man you're talking about' (Mk 14:71). As mentioned above, all four Gospels attest that women like Mary Magdalene, were the first to discover his empty tomb and thus the first to share the news of his resurrection (e.g. Mk 16:4; In 20:18). Another noteworthy event is the presence of 'the women' (Ac 1:14) when the Holy Spirit appeared upon the 12 apostles during Jewish Pentecost, clearly indicating equality between the sexes.

It is clear from the above elaboration that women in the Bible have been awarded seminal and crucial roles in education, learning, apprenticeship, prophesy, distributing messages, and teaching, and not least, as mother of Christ.

\section{Women in positions of prominence or leadership}

Throughout the Bible, men tend to have the public positions of formal power. This is visible, for example in the books of Samuel, whereby the Israelite society is described as centralised and hierarchical, run by men for men. This is, however, not so visible in the book of Judges, where charismatic leadership demonstrated through Deborah and Jael (both also mentioned before) is suited to a more fragmented and decentralised society (Jdg 4-5).

Some may argue that women's first step of leadership is recognised in the Fall (Gn 2:17), whereby Eve can be recognised as the protagonist, demonstrating curiosity, hunger for knowledge and willingness to test limits, traits that are human and often recognised in heroes and heroines in many cultures (Stewart 2012a). One may also say that she ate the fruit out of hunger for wisdom, as the serpent had stated that eating the fruit would open her eyes to good and evil. Wisdom is a trait often favourably associated with leadership (Baldock 2018).

Zipporah, Moses' wife, is the third woman to save the life of Moses, by performing a ritual (Ex 4:24-26) not normally associated with women, thus indicating that she may have held a leadership position within the priesthood, even though the book of Exodus claims that these roles are reserved for males (Ex 28-29).

Miriam, believed to be Moses' sister, demonstrates both courage and loyalty when she guards her brother hidden on the bank of the Nile (Ex 2:4-8). She is further portrayed as a prophet, leading the women with her dance and playing on the tambourine (Ex 15:20-21). Miriam's leadership is further hinted at in her and Aaron's dispute with Moses (Ex 12:1-2), resulting in Miriam being punished by God (Nm 12:10). Fragmented non-canonical manuscripts suggest that Miriam played an important role in worshipping, pointing to the possibility of hymns that we no longer have access to, celebrating women (James 2012; Junior 2012).

The parallel in the roles of Miriam and Mary are obvious, as both are pointing to the redemption through the activities and lives of Moses and Jesus, the latter also may be described 
as a new Moses, and both in praising God for his mighty deeds through their songs (Ex 15:21, Lk 1:46-55).

A story of two powerful women is further found in Judges $4-5$, where the prophet and judge Deborah are portrayed together with Jael, the wife of Heber the Kenite. While Deborah commanded troops to war, Jael ended the suffering in a somewhat brutal manner, as described above (FrymerKensky 2004).

Deborah is portrayed as an outstanding leader in Israel (Jdg 4:4), not only advising the military leader Barak, but in fact leading the troops, in addition to being recognised publicly for her success in guiding armies of warriors (Jdg 4:6). Barak, her general, seeks to trust in God when going to battle, but simultaneously insists that Deborah joins him in the fray (Jdg 4:8). The story states that Deborah 'was leading' Israel (Jdg 4:4), which traditionally has been translated as 'judging', a phrase used when referring to the charismatic leaders with political powers recognised in Israel prior to the introduction of a monarchy. Such leaders normally gained their powers and were bestowed these positions after saving Israel in battle. It is uncertain whether this is how Deborah got her political powers and public recognition. Her leadership and role in public life starts before the narrative when her story is captured, hence her true road to leadership is not recorded and therefore this important part of her life is somewhat mysterious. Included in her powers, is her ability to foresee the future by reading the stars and their alignment to guide Israel into winning battles, an ability making her one of the few prophet women (Frymer-Kensky 2004).

The story of Jael who kills the enemy, offers few explanations for her brutal actions, hence leaving room for moral ambiguity (Jdg 4:18-21). At first Jael comes across as any other woman, being at home, far from the battlefield. Sisera, the commander of Israel's enemy army, is welcomed into her home (tent) to hide, as his soldiers have fled the battle in panic. She brutally kills him during his sleep by hammering a tent peg into his temple, all by her own planning and design. Jael is depicted as a heroine in the story, blessed by women and praised by Deborah (Jdg 5:24-27). Though her actions are condemned by some, the scriptural narrative does not advise punishment for her actions, but rather depicts her as a self-motivated heroine who afforded Sisera a gruesome and deserved fate. The Talmud uses the case of Jael to argue good intentions as righteous, hence praising her as one of the matriarchs of Israel (Stewart 2012b). The story of Jael bears strong resemblance to the story of Judith, both killing the enemy generals. There are, however, some interesting differences: while Judith's physical appearance is her weapon that ultimately saves Israel, Jael's appearance is not a subject, nor is Sisera reported to seek anything but her help.

Both Deborah and Jael's positions as leaders in the religious and political sphere have been intensely debated among Christian thinkers throughout the centuries. While some have tried to diminish their actions, others like the prominent
American suffragist Elisabeth Cady Stanton (1815-1902), have praised their heroic actions, arguing the need to see the inspiration this brings to women in general (Cady Stanton 1895). In any case, Judges 4-5 offers the stories of two powerful, forceful female protagonists, exerting leadership at crucial times, and these are hard to brush aside (Stewart 2012b).

The Queen of Sheba is yet another example of a female leader with a more formal appointment. She demonstrates wisdom above power, as she is portrayed as a woman with a sharp intellect, which she used within both business and political life (1 Ki 10:1.13; Mt 12:42). To some extent one may say that her knowledge was so great as even to include knowing what she did not know. Her travels, despite danger, to broaden her wisdom is therefore relevant, making her story not only a story of her own intelligence, but also a story of independence in a time when women might not have been granted the same freedom as men.

Not all the female leaders in the Bible are remembered for their good deeds. Athaliah (2 Ki 11 and 1 Chr 22-23) was blinded by ambition, treating other humans with a lack of respect, while totally lacking loyalty to family and her own faith. She is portrayed as a person corrupted by power, demonstrating both evil deeds and manipulation of others, thus far from a role model for any leader, irrespective of gender. That the character of Athaliah is pictured in this very human way, could indicate that woman did have real powers, and that they were not only to be lifted in certain select scriptural narratives as beautiful, pious and heroic. With such a human depiction of Athaliah, it may be argued that this is a sign of real gender equality as valid scriptural ethos, also when power positions are assessed.

Women's participation in high level leadership in the Bible, is closely linked to choices and risk. Recent sources advocate that the appointment of female Christian deacons was as real as the appointment of males (MacCulloch 2010). The women did not get these titles merely because they were married to male leaders; on the contrary, they are believed to have deserved these appointments. Linked to this are also clear indications that women in the early Christian era enjoyed personal flexibility and social freedom. Being part of the early churches did, however, often involve a personal choice. As an example, Paul addresses the 'virgins' in 1 Corinthians 7:34, indicating that the women are holy in spirit and body. An important aspect of this is that the concept of purity and the link to divinity, is, however, not invented by the early Christians. The Roman world already had embraced this within their view on society (MacCulloch 2010).

The above demonstrate examples of women's participation in leadership roles as described in the Bible. It is evident that women in the Bible have been awarded important and crucial roles related to many, if not all societal realms, and that women carry their full weight, on all levels of leadership, in all parts of societal activity. 


\section{Conclusion}

The above findings demonstrate that the Bible contains numerous examples of strong female figures in formal or informal leadership positions in society. The Bible text cannot responsibly be used to justify inequality between genders, even though women throughout the ages have been subject to social, societal, cultural and economic inequality. The portraying of women in the Bible lends neither support to the exclusion of women from societal life, nor from the organisational realm or corporate world of leadership. Even though some women remain nameless in the Bible, the named women are often cast as historically important individuals. They are exerting substantial informal or formal powers, offering both inspiration and guidance to women of today, no matter the societal vantage point in use - also from an organisational and corporate and leadership point of view. Many of them are portrayed as strong auto-motivated females with the courage to lead in all areas of life, whether in crises and wars - or everyday family life. Women's roles in education, learning, apprenticeship, and teaching are visible, and not least notable in Jesus' relation to women in general and to the females in his life. As have been demonstrated, in spite of the inequality of women in the Mediterranean culture of antiquity, both in the pre-Roman era of the Old Testament era and during Roman times in the New Testament era, and the cotemporaneous quest for subordination, the Christian community utilised the leadership gifts of women. They did not just follow the cultural umwelt, but actually introduced a revolutionary culture of gender sensitivity. As highly visible women in the Bible have been awarded important and crucial roles on all levels of society, we may draw inspiration and guidance from the biblical texts today, for supporting gender equality on all levels and realms of organisation, corporations and society.

As a closing remark I would highlight, that women may connect with the above addressed scriptural texts in divergent ways, influenced by demographic, social and geographical contexts.

\section{Acknowledgements}

This article is partially based on the author's thesis for the degree Doctor of Philosophy in Ethics at the North-West University, South Africa, with promoter Prof. Dr J.M. Vorster and co-promoter Prof. Dr A.L. Rheeder, received July 2019, available here: https://repository.nwu.ac.za/bitstream/ handle / $10394 / 33563 / 30114020 \% 20$ C\%20Bosterud. pdf?isAllowed=y\&sequence $=1$.

\section{Competing interests}

This research received no specific grant from any funding agency in the public, commercial, or not-for-profit sectors.

\section{Author's contributions}

I declare that I am the sole author of this research article.

\section{Ethical considerations}

This article followed all ethical standards for a research without direct contact with human or animal subjects.

\section{Funding information}

This research received no specific grant from any funding agency in the public, commercial, or not-for-profit sectors.

\section{Data availability}

Data sharing is not applicable to this article as no new data were created or analysed in this study.

\section{Disclaimer}

The views and opinions expressed in this article are those of the author and do not necessarily reflect the official policy or position of any affiliated agency of the author.

\section{References}

Alexander, T.D. \& Baker, D.W. (eds.), 2002, Dictionary of the Old Testament: Pentateuch A compendium of contemporary biblical scholarship. InterVarsity Press.

Alter, R., 2018, The five books of Moses: A translation with commentary, Norton, New York, NY.

Baldock, J., 2018, Women in the Bible, Arcturus Publishing, London.

Bøsterud, C.E., 2020, 'Gender equality in corporate South Africa: A Christian ethical approach', in C.E. Bøsterud, Christian ethics and political economy: Markers for a developing South Africa, pp. 101-136, AOSIS, Cape Town. (Reformed Theology in Africa Series, vol. 3)

Cady Stanton, E., 1895, The woman's Bible, https://archive.org/stream/ thewomansbible09880gut/wbibl10.txt

De Riencourt, A., 1989, Woman and power in history, Honeyglen Publishing, London.

Dombkowski Hopkins, D., 2012, 'Judith', in C.A. Newsom, S.H. Ringe \& J.E. Lapsley (eds.), Women's Bible commentary, pp. 383-390, Westminster John Knox Press, Louisville, KY.

Frymer-Kensky, T., 2004, Reading the women of the Bible, Random House, New York, NY

Hylen, S.E., 2018, Women in the New Testament world, Oxford University Press, Oxford. (Essentials of Biblical Studies).

James, E., 2012, 'Miriam and her interpreters', in C.A. Newsom, S.H Ringe \& J.E. Lapsley (eds.), Women's Bible commentary, pp. 67-69, Westminster John Knox Press, Louisville, KY.

Junior, N., 2012, 'Exodus', in C.A. Newsom, S.H Ringe \& J.E. Lapsley (eds.), Women's Bible commentary, pp. 56-66, Westminster John Knox Press, Louisville, KY.

MacCulloch, D., 2010, Diarmaid MacCulloch's: A history of Christianity, Ambrose Video Publishing, New York, NY

Niditch, S., 2012, 'Genesis', in C.A. Newsom, S.H. Ringe \& J.E. Lapsley (eds.), Women's Bible commentary, pp. 27-45, Westminster John Knox Press, Louisville, KY.

O'Collins, G., 2009, Christology: A biblical, historical, and systematic study of Jesus, Oxford University Press, Oxford.

Reinhartz, A., 2012, 'The Greek book of Esther', in C.A. Newsom, S.H. Ringe \& J.E. Lapsley (eds.), Women's Bible commentary, pp. 396-403, Westminster John Knox Press, Louisville, KY.

Sanders, E., 1995, The historical figure of Jesus, Penguin Books, London.

Scheuer, B., 2015, 'Huldah: A cunning career woman?', in B.E.J.H. Becking \& H. Barstad (eds.), Prophecy and prophets in stories, pp. 104-123, Brill, Leiden.

Stewart, A.W., 2012a, 'Eve and her interpreters', in C.A. Newsom, S.H. Ringe \& J.E. Lapsley (eds.), Women's Bible commentary, pp. 46-50, Westminster John Knox Press, Louisville, KY

Stewart, A.W., 2012b, 'Deborah, Jael, and their interpreters', in C.A. Newsom, S.H. Ringe \& J.E. Lapsley (eds.), Women's Bible commentary, pp. 128-132, Westminster John Knox Press, Louisville, KY.

Teubal, S.J., 1984, Sarah the priestess: The first matriarch of Genesis, Swallow Press, Athens, $\mathrm{OH}$.

White Crawford, S., 2012, 'Esther', in C.A. Newsom, S.H. Ringe \& J.E. Lapsley (eds.), Women's Bible commentary, pp. 201-207, Westminster John Knox Press, Louisville, KY.

Willmington, H., 2019, God-ordained leaders - Prophetesses, https://digitalcommons. liberty.edu/ordained_leaders/8 